\title{
Adaptation as a Water Resource Policy Challenge -Institutions and Science
}

\author{
David Lewis Feldman \\ Department of Planning, Policy and Design and Political Science, University of California, Irvine, USA \\ Email: feldmand@uci.edu
}

Received February 2, 2013; revised March 6, 2013; accepted March 19, 2013

Copyright (C 2013 David Lewis Feldman. This is an open access article distributed under the Creative Commons Attribution License, which permits unrestricted use, distribution, and reproduction in any medium, provided the original work is properly cited.

\begin{abstract}
Adaptation is the pursuit of active, deliberate measures to enhance humankind's capacity to manage water supply and attenuate demand in the face of climate uncertainty. This article contends that worsening constraints upon freshwater due to climate variability demand concerted, imaginative, science-based solutions. These solutions must join creative management to co-production of climate knowledge. Through a series of case studies, we analyze the need for adaptation approaches to prevail over climate variability, and the role of these factors to facilitate their implementation. We also examine how translation of climate knowledge is helping spur adaptation at various spatial levels. These experiences point to the challenges in adaptation, and the adversity various regions will be faced if we do not.
\end{abstract}

Keywords: Adaptation; Climate Change; Translational Science; River Basins; Megacities

\section{Introduction}

Climate scientists, hydrologists, and others contend that the continued concentration of carbon dioxide and methane emissions will alter the climate in various ways: global average temperatures will rise, for example, and dramatic changes in precipitation could adversely affect the world's freshwater supply. Rainfall intensity may increase in some regions and decline in others, while the seasonal balance between snow and rain might also shift, affecting local economies. Higher temperatures could increase evaporation and transpiration-the rate at which plants give up moisture to the atmosphere, while reduced soil moisture affects farming.

Over longer periods, shifts in vegetation cover over entire regions-from forest to grassland or grassland to desert-may occur. Accelerated melting of polar and glacial ice, another probable result of climate change, would lead to greater sea-level rise and salt-water intrusion into coastal estuaries, affecting fisheries and threatening urban drinking water supplies [1].

Many scientists believe these changes are not only likely scenarios, but that current protracted drought in some regions, and unprecedented flooding in others, are harbingers of worse to come. While debate over whether and to what extent any given climatic event may be attributable to global climate change is far from settled, there is growing consensus that the increasing frequency of water-related extreme climate events is probably the result of human-induced climate change [2].

Adaptation is the pursuit of measures to enhance our ability to manage water supply and attenuate demands in the face of climate uncertainty. It requires imaginative management as well as good science, and it depends on the ability to translate knowledge into language useful to decision-makers and the public. It also includes activities undertaken for reasons other than climate change (see Table 1).

We focus on three venues where climate variability affects water management, and where adaptation is being pursued: megacities, river basins experiencing drought and/or flooding, and global venues where these issues are being discussed, and ways identified, to reduce the impacts of climate change on freshwater through diffusion of innovation across national boundaries.

\section{Venues for Freshwater Adaptation}

\subsection{Megacities and Water Management}

Megacities are urban centers composed of tens-ofmillions of people and are a growing phenomenon in developing nations where some $80 \%$ of the planet's urban population resides. Since 1950, the urban populace of Africa, Asia, and Latin America alone has swelled five-fold [3]. Large cities generally, and megacities in 
Table 1. Some adaptation options for freshwater.

\begin{tabular}{|c|c|}
\hline Supply-side & Demand-side \\
\hline Prospecting and extraction of groundwater & Improvement of water-use efficiency by recycling water \\
\hline $\begin{array}{l}\text { Increasing storage capacity by building reservoirs } \\
\text { and dams }\end{array}$ & $\begin{array}{l}\text { Reduction in water demand for irrigation by changing the cropping calendar, crop mix, irrigation } \\
\text { method, and area planted }\end{array}$ \\
\hline Desalination of sea water & Reduction in water demand for irrigation by importing agricultural products, i.e., virtual water \\
\hline Expansion of rain-water storage & Promotion of indigenous practices for sustainable water use \\
\hline $\begin{array}{l}\text { Removal of invasive non-native vegetation from } \\
\text { riparian areas }\end{array}$ & Expanded use of water markets to reallocate water to highly valued uses \\
\hline Water transfer & $\begin{array}{l}\text { Expanded use of economic incentives including metering and pricing to encourage water } \\
\text { conservation }\end{array}$ \\
\hline
\end{tabular}

From: IPCC fourth assessment report, climate change: working group II: impacts, adaptation and vulnerability, 2007 , Table 3.5.

particular, are often located some distance from the water sources their swelling populations require [4]. This leads to an important and in some ways ironic quandary. Large cities often divert water from outlying rural areas which, in turn, produce the food and fiber that directly support their teeming populations.

In recent years, large cities in developed and developing countries have instituted measures to secure resilient water supplies. While partly driven by climate concerns, the immediate drivers of these adaptation efforts have been population growth, the need to share supplies with neighboring communities, and demands to restore threatened habitat. While many examples could be cited, four large cities - representing an array of baseline climatestypify some of these drivers: New York, Tokyo, Los Angeles, and Mexico City.

Since the 1980s, New York-a "wet" city (with an average of 50" of precipitation per year, half in the form of snow)-has found that even relative abundance can become a deficit given population growth and antiquated infrastructure. Since the late 1970 s the city has undertaken measures to reduce residential water use by $30 \%$, repair aqueducts from the Catskills and Croton watersheds to forestall leaks, and evaluate the possible impacts of climate change. Working with local universities and environmental organizations, officials are trying to determine how sea-level rise and storm surges will affect water and wastewater infrastructure; how higher temperatures and lower precipitation will impact public supply and ecosystem health; and, whether capital planning needs to adapt to these changes can be anticipated [5-9].

Tokyo is also located in a traditionally wet climate, receiving some 60 inches of precipitation per year, most of which falls as rain during mid-summer. After World War II, rapid in-migration and economic growth dramatically increased water demands at the same time planners decided to pave over small waterways to facilitate urban expansion. Increased consumption led to declines in groundwater and land subsidence. Since the 1980s, climate change concerns, including local "heat island" effects from urbanization leading to additional energy use, have prompted introduction of large-scale wastewater reuse, non-potable storm-water harvesting, groundwater withdrawal restrictions, and aggressive conservation $[10,11]$.

By comparison, Los Angeles and Mexico Citylocated in dryer climates-face comparable or worse challenges. Receiving some 15 inches of rain per year, Los Angeles basin providers have long employed public education and outreach programs to reduce residential uses. In 2011, average daily demands remained the same as in 1980, despite 1.1 million more people living in Los Angeles County. Storm-water capture and wastewater reuse are among additional alternatives being pursued, and climate change is now embraced in regional planning efforts such as those of the Metropolitan Water District of Southern California-the area's principal water provider since the 1930s - and the LA Department of Water \& Power. Among questions for which answers are being sought are: how will climate change complicate water rights exchanges with rural areas and affect water rights acquired from regional agricultural users; and, how might seismic events disrupt already precarious imported supplies [12-14]?

Finally, Mexico City, one of world's largest cities (>20 million), and recipient of some 28 inches of rainfall annually, exemplifies the complexities of adaptation in third world cities. Plans long underway to adapt to growing water demands are now being adjusted for climate change. Unsurprisingly, most of these plans hinge on additional water transfers from outlying regions to recharge local aquifers and surface reservoirs. Efforts are also being pursued, however, to reduce residential water demand, use more reclaimed wastewater for local agriculture and non-potable uses, and employ storm-water capture for groundwater recharge and some community uses. Given the availability of public investment funds and low water tariffs charged in Mexico, the likely effectiveness of these measures is subject to considerable 
debate [15-17].

\subsection{Adaptive River Basins}

Three ambitious if divergent examples of basin-wide adaptation efforts to manage drought and floodingcaused by climate variability-are found in Nigeria, Bangladesh, and Australia.

In 2002, the World Conservation Union and the UK's foreign assistance agency partnered with the government of Nigeria in an effort focused on the Hadejia-Jama'are basin to build "local water resources management capacity" in a region long experiencing the vicissitudes of alternating flood and drought. Among the unique features of the Joint Wetlands Livelihood are improving use of local knowledge; demonstrating pilot-scale, best-management practices to restore the region's economy and ecology by showing how to conduct dry-season grazing, recharge groundwater, and restore waterfowl habitat. Most innovatively, local level forums comprised of farmers, women's groups, and villagers engage in community-level training, apply local knowledge to water management, and directly participate in policy making by role-playing scenarios to manage parts of the watershed in ways that maximize equity while protecting agricultural productivity. Central to these scenarios is a process of debating and rank ordering measures $[18,19]$.

By contrast, the Bengali Delta of Bangladesh consistently suffers from too much water, with chronic flooding from cyclones and monsoonal storms a toofrequent occurrence. While thousands have died from floods, there is fear that sea level rise caused by melting glaciers will worsen floods and displace upwards of $15 \%$ of the country's 160 million. Because the Ganges and Brahmaputra River deltas constantly shift, securing their banks and protecting rich farmland is difficult. In the 1990s, a World Bank plan backed by France, Japan, and the US, proposed some $8000 \mathrm{~km}$ of dikes to control these streams at an estimated cost of $\$ 10$ billion, together with sea walls to resist cyclone-induced waves. Local farmers opposed these plans because their lands would be taken, while the Intergovernmental Panel on Climate Change, criticized them because local soils were too unstable to support such efforts.

As an alternative, local villagers and farmers, working with NGOs including UK-based Practical Action and US-based CARE, advanced local-scale programs to adapt to flooding, including 2-foot-high concrete plinths topped with inexpensive jute panel walled homes that are less likely to be washed away by tropical storms; reintroduction of formerly forgotten farming techniques such as Baira cultivation and floating gardens suited to areas subject to lengthy inundation, introduction of salt-tolerant varieties of rice; and, conversion of some paddies to shrimp and crab raising. These innovations would not have been introduced without incorporating the knowledge of local farmers and villagers [20,21].

Finally, since 1985, Australia's Murray-Darling Basin has witnessed a significant set of policy changes following negotiation of the Murray-Darling Basin Compact commission (MDBC). This agreement between New South Wales, Victoria, S. Australia and the federal government provides an integrated management scheme for the region which is home to over $40 \%$ of the country's farms, annually produces $\$ 10$ billion of crops and livestock, and provides water to over 3 million (see Figure 1).

Key to its adaptive-ness are two features: a sustainable management program that engages local communities in an interactive, participatory process to evaluate factors adversely affecting water, monitor ever-changing conditions, and work with community groups to develop longterm management strategies; and a science-for-policy translational effort co-sponsored by the MDBC that monitors long term (e.g., the recent Millennium Drought) drought, El Nino/La Nina trends, and incorporates longer-term data into river system and groundwater models. While its primary goals are reducing high salinity from irrigation, restoring ecological health, and managing long-term drought planning for climate variability have become central to its role. MDBC coordinates individual state initiatives to compensate for climate variability, diversions, allocate water to ensure adequate in-stream flow, and employ water markets to sustain environmental quality [22-24].

Conflicts persist in the basin, however: environmentalists and farmers continue to debate the amount of water needed to restore in-stream health. In November 2012, for instance, the federal parliament set up a $\$ 1.7$ billion fund to purchase water rights from farmers in order to

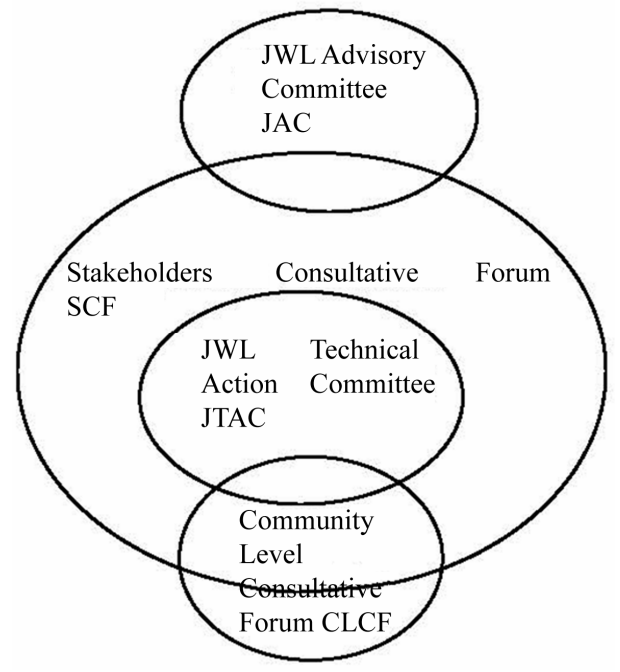

Figure 1. Schematic of stakeholders' consultative forum (from: Chiroma et al.). 
maintain adequate flow in those parts of the basin most ecologically vulnerable [25].

\subsection{Global Diffusion}

In the past 25 years, international convocations have sought to address climate-related adaptation problems facing water management in an attempt to establish global protective standards and better diffuse adaptation experiences. Examples of such efforts include UNCED's Local Agenda 21 (1991); the UN Millennium Development Summit (2000); the World Civil Society Forum (2002); and the UNEP Foresight Process on Emerging Environmental issues (2012).

The International Council of Local Environmental Initiatives (1990), comprised of some 1200 local governments worldwide was formed in 1990 following the World Congress of Local Governments, seeks to demonstrate local strategies that can be disseminated to other cities and sub-national regions. ICLEI is currently best known for providing technical consulting, training, and information services to build capacity, share knowledge, and support local governments in implementing innovations in energy, water, and biodiversity. It also adroitly publicizes and awards notable "success stories" in order to promote emulation by other cities. ICLEI has sponsored numerous studies of urban energy use that have been useful for gauging growth in production and consumption in large cities in highly-developed, as well as developing countries. Its premise is that locally-designed initiatives can provide effective, cost-efficient ways to achieve sustainability [26-28].

ICLEI has also undertaken local and regional climate change mitigation and prevention initiatives without waiting for national-level interventions to first occur. Beginning in the early 1990s, for instance, the UN's Conference on Environment and Development's (UNCED) Local Agenda 21 Program, as well as Article 10 of the Rio Declaration on Environment and Development began to encourage developing countries to restructure their national development and environmental protection plans to better embrace local-level decision-making in plan formulation and implementation.

The primary goal of these activities has been to ensure that investments made by UN-affiliated organizations would be vetted through local NGOs and community groups, as well as by scientific specialists who may not be adequately represented in national decision-making forums. The anticipated payoff for these countries (and for their regions and cities) is heightened capacity to leverage development funds so as to tackle issues of infrastructure resiliency and resource vulnerability (e.g., sealevel rise, water supply, renewable energy projects).

A second goal of ICLEI is to place local-level deci- sion-makers in a better position to leverage national as well as local resources by demonstrating how they have benefited from what they have learned through publicizing efforts and depicting successful cases as models worthy of emulation. This better enables development of integration skills among organizational participants. Integration skills refer to the ability to bridge different ways of knowing a single issue. Since 2009, for instance, ICLEI has heavily invested in a Young Municipal Leaders Initiative which selects some two-dozen junior mayors and municipal council officials to participate in a two-year capacity-building alumnus-teaching program to ensure continuous knowledge sharing and long-term engagement in its networking activities.

Other forums where integration-type activities have occurred include regional integrated assessment activities that have been successful in articulating new research priorities in the US; in regional climate-response planning activities in the Northeast US specifically engineered and coordinated by ICLEI and its Cities for Climate Protection (CCP) Campaign; and, in other regional endeavors in which scientists and policy-makers work together to manage drought, flooding, and promoting local practices for managing water resources in a sustainable manner through training, capacity-building, and sharing innovations on conservation, water-use efficiency, and integrated water management approaches in over 70 countries [29].

\subsection{Co-Production and Translation of Science}

Translating climate knowledge to make it useful to lay audiences is a huge adaptation challenge. There's a huge gap in the way scientists talk about climate change and the way farmers, villagers, urban residents, and other lay audiences talk about water problems. Translation is an effort to literally "simplify" science. Efforts taking place in Brazil and the Nile Basin in Africa show how this may be done effectively.

Since the 1990s, the northeast Brazilian state of Ceara has sought to institute legal reforms in response to drought and competing water claims-and to foster collaboration between scientists and local farmers. In coordination with federal agencies, a series of participatory management councils have been introduced in the Lower Jaguaribe-Banabmuiú River basin to negotiate water allocation agreements among users.

In a departure from traditional top-down decisionmaking, técnicos (staff scientists) work with farmers to: combine local knowledge of drought/flood impacts with long-term expert weather predictions; and help farmers and local governments better manage reservoirs, flood, and drought. Results have thus far yielded a willingness among farmers to share management of local water 
supplies, while the state water management authority permits locals to monitor conditions. Local users, for their part, hold greater trust in state-level information [30, 31].

Since 1998, the 10 countries of Africa's Nile basin (Kenya, Burundi, Rwanda, Tanzania, Eritrea, Ethiopia, Sudan, Egypt, Uganda, and Congo) have tried to negotiate an agreement to share the waters of the basin equitably, acknowledging the needs of fast-growing upstream countries while respecting-where possible-the established rights of Sudan and Egypt. The latter-which have the basin's largest populations-are reluctant to relinquish withdrawal rights, while upstream Ethiopia is committed to harnessing tributaries for hydroelectricity and water supply without Egypt's permission, creating additional friction. While solutions are debated, Lake Victoria, a major source of the Nile, falls some 2.5 meters every three years due to climate change.

Despite such acrimony, some adaptation is occurring in sub-basins: including international support for irrigation improvements, groundwater management, and rural electrification projects. Moreover, local communities, NGOs, scientists and aid organizations are working together to design solutions, identify funding sources, and share information [32-34].

\section{Conclusions}

Prospects for climate change are compelling communities across the globe to adapt to freshwater shortages and other alterations. Cities and river basins are actually well-suited for undertaking adaptation efforts if the political will can be found to mobilize hard choices. Adaptation will require: 1) better communication between scientists and end-users, facilitated by efforts to formalize dialogue between them (e.g., Brazil, Nigeria); 2) adaptive management-an approach emphasizing social learning and incremental solutions that are reversible if they fail (e.g., Bangladesh, Nile Basin, megacities); and, 3) recognition that sounds knowledge and effective collaboration go together-experts must reach-out to local water users and embrace cultural, social, and ethical concerns if the world is to face global climate change's impacts on freshwater.

In sum, climate change and extreme variability will force us to adapt to freshwater shortages, alterations in distribution. While adaptation requires better communication between scientists and end-users-thus, reform of water institutions to facilitate dialogue among them-as we have seen, impediments to these processes cannot be underestimated. They include antiquated models of science-for-policy which predicate that scientists generate information without consulting users or incorporating local knowledge.

\section{Acknowledgements}

D. Feldman thanks the program committee for the ESF Junior Summit-Water: Unite and Divide-Interdisciplinary Approaches for a Sustainable Future for the opportunity to present an earlier version of this paper in Stresa, Italy in August 2012.

\section{REFERENCES}

[1] Climate Institute, “Water and Climate Change,” 2010. http://www.climate.org/topics/water.html

[2] P. H. Gleick and M. Heberger, "The Coming Mega Drought,” Scientific American, Vol. 306, No. 1, 2012, pp. 1-14.

[3] D. Satterthwaite, "Will Most People Live in Cities?" British Medical Journal, Vol. 321, No. 7269, 2000, pp. 1143-1145.

http://www.pubmedcentral.nih.gov/articlerender.fcgi?arti $\mathrm{d}+1118907$ doi:10.1136/bmj.321.7269.1143

[4] United Nations Population Fund (UNFPA), "State of World Population 2007: Unleashing the Potential of Urban Growth," United Nations Population Fund, New York, 2007.

[5] New York City Department of Environmental Protection, “2010 Drinking Water Supply and Quality Report,” Department of Environmental Protection, Flushing, 2010. http://www.nyc.gov/html/dep/pdf/wsstate10.pdf

[6] New York City, Department of Environmental Protection, “Drought Management Plan and Rules," 1998.

[7] New York State Department of Environmental Conservation, “New York City Watershed Program,” 2010. http://www.dec.ny.gov/land58597.htm

[8] New York State Department of Environmental Conservation, "Facts about the New York City Watershed," 2010. http://www.dec.ny.gov/lands/58524.html

[9] H. Shultz, "Some Facts on the New York City Water and Sewer Supply System,” Citizens’ Housing and Planning Council, New York, 2007.

[10] Bureau of Waterworks, Tokyo Metropolitan Government, "Water Supply in Tokyo," 2011.

http://www.waterworks.metro.tokyo.jp/eng/supply/index. html

[11] H. Blanco, et al., "The Role of Urban Land in Climate Change," Climate Change and Cities: First Assessment Report of the Urban Climate Change Research Network, 2007, p. 240.

[12] Los Angeles Department of Water and Power, "Mandatory Water Conservation-Fact Sheet,” 2009.

[13] Los Angeles Department of Water and Power, "Urban Water Management Plan,” 2010. www.ladwp.com

[14] Los Angeles Department of Water and Power, "The Story of the Los Angeles Aqueduct,” 2010. http://wsoweb.ladwp.com/Aqueduct/historyoflaa/

[15] T. M. Downs, "Sustainability of Least Cost Policies for Meeting Mexico City’s Future Water Demand,” Water 
Resources Research, Vol. 36, No. 8, 2000, pp. 23212339. doi:10.1029/1999WR900234

[16] C. Tortajada and E. Casteian, "Water Management for a Megacity: Mexico City Metropolitan Area,” Ambio, Vol. 32, No. 2, 2003, pp. 124-129.

[17] Institut de Recherche pour la Developpement, "Water Supplies to Mexico City,” 2012.

http://en.ird.fr/the-research/the-research-projects/water-su pplies-to-mexico-city

[18] M. J. Chiroma, D. Yahaya, D. Kazaure, B. Yahya, A. Karaye and J. Gashua, "Water Management Issues in the Hadejia-Jama’are-Komadugu-Yobe Basin: DFID-JWL and Stakeholders Experience in Information Sharing, Reaching Consensus and Physical Interventions.” http://www.iwmi.cgiar.org/research_impacts/Research_T hemes/BasinWaterManagement/RIPARWIN/PDFs/14\%2 0Muhammad\%20Chiroma\%20SS\%20FINAL\%20EDIT.p df

[19] B. Lankford, "Facilitation of Water Sharing Arrangements in the Hadejia Jama'are Komadugu Yobe Basin (HJKYB) - With the River Basin Game Dialogue Tool,” Overseas Development Group (ODG), School of Development Studies, University of East Anglia, Norwich, 2005.

[20] D. Belt, “The Coming Storm,” National Geographic, Vol. 219, No. 5, 2012, pp. 58-83.

[21] S. Robinson, "How Bangladesh Survived a Flood,” New York Times, 2007.

http://www.time.com/time/world/article/0,8599,1685330, 00.html\#ixzz1ctqiWiPs

[22] Living Victoria Ministerial Advisory Council, Department of Sustainability and Environment; Victorian Government, "Living Melbourne, Living Victoria Roadmap," 2011.

[23] Murray-Darling Basin Authority, “About MDB Initiative,” Canberra City, 2002.

http://www.mdbc.gov.au/about/governance/agreement_hi story.htm

[24] N. Martin, "Watershed Management in the Murray Darling Basin, Australia,” C. W. Slaughter and N. Berg, Eds., Proceedings of the Ninth Biennial Watershed Management Council Conference, Oakland, 2006, University of
California Water Resources Center Report No. 107, pp. 51-56.

[25] L. Vasek and L. Wilson, “'Long-Overdue’ Murray-Darling Basin Plan Becomes Law,” The Australian, 2012. http://www.theaustralian.com.au/in-depth/murray-darling -crisis/long-overdue-murray-darling-basin-plan-becomeslaw /story-e6frg6px-1226521990067

[26] (ICLEI) International Council on Local Environmental Initiatives, "Municipal leaders' Communiqué to the Conference of the Parties to the UN Framework Convention on Climate Change,” Berlin, 1995.

[27] (ICLEI) International Council on Local Environmental Initiatives, "ICLEI's Climate Resilient Communities Program Addresses Adaptation, Vulnerabilities," ICLEILocal Governments for Sustainability, 2007. http://www.iclei.org/index.php?id=1487\&tx_ttnews

[28] (ICLEI) International Council on Local Environmental Initiatives, "ICLEI-Local Governments for Sustainability: Local Solutions to Global Challenges,” ICLEI Center, Bonn, 2010.

[29] H. Selin and S. D. VanDeveer, "Climate Leadership in Northeast North America," In: H. Selin and S. D. VanDeveer, Eds., Changing Climates in North American Politics, MIT Press, Cambridge, 2009, pp. 11-135.

[30] M. C. Lemos and J. L. F. Oliveira, "Can Water Reform Survive Politics? Institutional Change and River Basin Management in Ceará, Northeast Brazil,” World Development, Vol. 32, No. 12, 2004, pp. 2121-2137. doi:10.1016/j.worlddev.2004.08.002

[31] M. C. Lemos and J. L. F. Oliveira, "Water Reform across the State/Society Divide: The Case of Ceará, Brazil," International Journal of Water Resources Development, Vol. 21, No. 1, 2005, pp. 93-107.

[32] “Nile Basin Initiative,” 2010. http://www.nilebasin.org

[33] "The Rights to the River," The Sustainable Water Resources E-Journal, 2009. www.waterresource.co.za/index.php?option=com_Content

[34] J. Fleishman and K. Linthicum, "Demands on the Nile imperil Egypt's Lifeline,” Los Angeles Times, 2010, pp. A-1, 6-7. 